\title{
Foreign policy in an era of digital diplomacy
}

\section{Внешняя политика в эпоху цифровой дипломатии}

\author{
DOI: $10.12737 / 2587-6295-2021-5-2-2021-117-123$ \\ УДК 32.019 .51 \\ Received: 19.06.2021 Approved: 24.06.2021 Published: 25.06.2021
}

\author{
Beznosov M.A. \\ Candidate of Political Sciences, Candidate of Sociological Sciences, Department of Civic \\ Engagement and Public Service, University of West Georgia, USA \\ e-mail: mbeznosov@westga.edu
}

\section{Безносов М.А.}

доктор философии в области политологии, канд. социол. наук, Департамент гражданской активности и государственной службы, Университет Западной Джорджии, США e-mail: mbeznosov@westga.edu

\begin{abstract}
This review is the analysis of the article «Foreign policy in an era of digital diplomacy» written by a scholar from Nigeria Dr. Olubukola S. Adesina. This article deals with the recent application and development of the so-called digital diplomacy in the field of politics and traditional diplomacy. It includes an extensive analysis of this phenomenon, its characteristics, its development, as well as the debates that accompany this new trend little studied so far. In addition, the article discusses the cases of the use and growth of digital diplomacy or ediplomacy, as it has been called in various spaces. In a very complete way, basic aspects of the concept of digital diplomacy are presented, from its various definitions to the controversy it has generated in the diplomatic community traditional slant. The entry of digital diplomacy into the diplomatic sphere is explained as an effect of the technological explosion of the 2000s. However, the author makes a clarification regarding the differences among various cases, in terms of implementation of this concept. Also, the discussion about the birth of a new type of diplomacy and new actors capable of influencing international relations is analyzed. Furthermore, new functions, roles and effects of social networks in the diplomatic world and their meanings for international relations are investigated. Finally, one of the strong points in this article is the analysis of the risks and benefits that digital diplomacy presents to the modern foreign policy making.
\end{abstract}

Keywords: foreign policy, digitalization of politics, digital diplomacy, social networks, soft power.

\footnotetext{
Аннотация

Эта рецензия нащелена на анализ статьи «Внешняя политика в эпоху цифровой дипломатии», написанной исследователем из Нигерии доктором Олубукола С. Адесиной. Эта статья посвящена недавнему применению и развитию так называемой цифровой дипломатии в области политики и традиционной дипломатии. Она включает в себя обширный анализ этого явления, его характеристик, его развития, а также дискуссии,
} 
которые сопровождают эту новую малоизученную тенденцию. Кроме того, в статье обсуждаются случаи использования и роста цифровой дипломатии или электронной дипломатии, как ее называют в разных сферах. В очень полном виде представлены основные аспекты концепции цифровой дипломатии, от ее различных определений до споров, которые она породила в традиционном уклоне дипломатического сообщества. Вхождение цифровой дипломатии в дипломатическую сферу объясняется эффектом технологического взрыва 2000-х годов. Однако автор дает пояснение относительно различий между разными случаями с точки зрения реализации этой концепции. Также анализируется дискуссия о рождении нового типа дипломатии и новых акторов, способных влиять на международные отношения. Кроме того, исследуются новые функции, роли и эффекты социальных сетей в дипломатическом мире и их значение для международных отношений. Наконец, одной из сильных сторон этой статьи является анализ рисков и преимуществ, которые цифровая дипломатия представляет для современной внешней политики.

Ключевые слова: внешняя политика, цифровизация политики, цифровая дипломатия, социальные сети, мягкая сила.

This article deals with the recent application and development of the so-called digital diplomacy in the field of politics and traditional diplomacy. The main purposes of this article are: to explain the evolution of digital diplomacy, to describe the characteristics of digital diplomacy, with particular emphasis on its definition and goals; to analyze the utilization of digital diplomacy and its effectiveness in various countries, and to classify the main benefits and risks of digital diplomacy.

The paper is divided into eight parts. The first one is an introduction where diplomacy is presented as one of the major instruments of foreign policy. The second part is a thorough explanation of what is meant by the digital diplomacy. The third part presents the theoretical framework that this paper's argument is based on. In the fourth part, the author explains the logic of the evolution of digital diplomacy. The fifth part is a comprehensive description of various cases of digital diplomacy around the world. The sixths and the sevenths parts are the most interesting parts of the paper because within them are the main information about the classification of the most important benefits and risks of digital diplomacy. The last part of the paper summarizes the main findings of this study.

The 21 st century, among other technological and social changes, created a global pool of over 3.6 billion internet users. It is hard to deny that this development has had a profound impact on public policy-making worldwide. In last 20 years we have been witnessing the process of emerging and evolving of the networked society. This social phenomenon had its cultural, economic as well as political implications. The new pattern of political communication through various social media created entirely new dynamics in domestic politics. The hard fact is that the politics became digitized. This change has been observed since the US presidential elections of 2008. But this kind of political communication has demonstrated its effectiveness especially in the recent American and European elections, with the rest of the world clearly adopting this innovation in politics as well.

The public policy process has been experiencing an equally profound «digitalization». And, obviously, in foreign policy-making this change has brought a number of modifications in diplomatic activities. Barack Obama and Donald Trump using tweeting as a tool of policy making have demonstrated the effectiveness and power of social media in the realm of modern 
politics and policy making. In the modern digitalized world, it opened new opportunities for what has been known as public diplomacy.

Recently, with globalization, public diplomacy has evolved, and it is now what we know as digital diplomacy. It is from the $90 \mathrm{~s}$, where a new form of diplomacy begins, restructuring new interests and global, governmental and social needs in the digital ecosystem.

Olubukola S. Adesina starts her article with a «Public Interest Statement» where she states that the paper «examines the concept of digital diplomacy, focusing on the use of digital media in the field of diplomacy and how countries are utilizing these tools in the pursuit of their foreign policies». The author highlights that the main focus of the paper is examination of «the opportunities and challenges these media offer for diplomatic activities». The main argument is that «countries cannot afford to be left behind in this era of digital diplomacy as they can greatly benefit from these emerging diplomatic trends» [8].

The first questions that Olubukola S. Adesina tries to answer throughout her work are the following [8]: What is digital diplomacy? How has digital diplomacy evolved? The introduction part stresses that the major factor «that has affected diplomacy in this modern age is the revolution in information and communication technologies (ICTs)». The transformation of communications is one of the most obvious secondary effects of experiencing the phenomenon of globalization. Thus, diplomacy has also been recreated and continues to evolve, seizing opportunities and managing the major challenges of high-level policy communication. The author attributes the fundamental changes in the conduct of diplomacy globally to the revolution in ICTs.

As it follows from the article, digital communication is a key tool for the activity of foreign ministries and their network of representations and consulates because it has the primary objective of reaching the citizen, using the different tools and digital platforms making use of Information and Communication Technologies. Many governments have developed digital diplomacy through social networks, improving their communication with citizens and their fellow citizens abroad.

In second part of the article, the author provides an overview of various definitions of digital diplomacy, stating that «there is no widely accepted definition or framework that covers the concept». The author echoes other scholars in concluding that «It may, thus, be safe to assume that current studies have only begun to scratch the surface of what digital diplomacy means and how it works" [8, p. 3]. This explains the absence in the current literature of a reliable conceptual framework for assessing the effectiveness of social media for public diplomatic purposes» [3]. Indeed, there is currently no single definition of digital diplomacy. The reference doctrine is predominantly U.S. It is in the U.S. that the subject of digital diplomacy is most studied. Some scholars define it as the electronic component of public diplomacy. According to others, however, digital diplomacy is substantiated in the use of the Internet to achieve political objectives, or, again, in the use of the web and social media to solve foreign policy problems.

It is universally accepted that digital diplomacy is a diplomacy resulting from the association of ICT and other electronic tools for conducting diplomatic activities. The substantial element of this definition lies in the fact that digital technologies present themselves as a functional tool for state interests in diplomatic relations. This is an emerging issue, with mainly application profiles, which does not follow a uniform development at an international level, since the approach of individual nations with respect to new technologies is different.

The research area is completely new and little debated. In fact, there are few studies concerning the implementation and dissemination of digital diplomacy and its impact on 
international policies. And the major reflection carried out by the research has mainly focused on the use of social media such as Facebook and Twitter by the main diplomatic representatives of states on foreign policy issues.

As it is well known, the term «digital diplomacy» has been initiated by several expert authors on the subject, mainly by Corneliu Bjola, professor of diplomatic studies at the University of Oxford, who states that: «Digital diplomacy is the use of networks for diplomatic purposes. Diplomacy could change practices of how diplomats participate in information management, public diplomacy, strategic planning, international negotiations or even crisis management» [2].

The author, however, adopted for the purpose of this article the Hanson's [4] definition of digital diplomacy as «the use of the internet and new Information Communications Technologies to help carry out diplomatic objectives, including its related goals». Digital diplomacy is, thus, seen as an important tool in furthering a nation's foreign policy as it enables direct interaction and engagement with foreign publics.

To summarize, the concept of digital diplomacy emerging from this part of the article contains the following characteristics:

- Use of social networks and digital platforms.

- New tools to disseminate, collect and measure information

- $\quad$ Reach for wider audiences

- Maintains the essential objectives of diplomacy.

The author concludes, that "world leaders and diplomats use social media, and Twitter in particular, to speak and engage directly to the audience they seek to influence. Also, diplomatic activities are increasingly supported by Internet tools. «Having said this, she follows by remarking that «while some diplomats embrace change as an opportunity to reform their profession, to others it represents a challenge to established conventions and may simply be «dangerous» to proven and accepted forms of conducting international relations - or to their own self-interest». She then mentions that, according to some scholars, «the impact of the Internet and the rise of social media platforms, particularly Twitter and Facebook, are generating a wealth of reactions» [5].

The next (third) part of the paper is theorizing the link between digital diplomacy and the perspective of soft power. From a geopolitical point of view, digital diplomacy allows for a greater affirmation of what Nye has defined as «soft power» in foreign policy. This concept summarizes the complex mechanism in which diplomacy is inserted to spread messages to a global audience, expanding its sphere of influence and promoting the interests of a certain state. The soft power embodies the ability of a nation to build consensus through persuasion and is nurtured through the dissemination of their culture and of their values. In this process, new media represent a strategic tool for international relations [6; 7].

The fourth part of the article tries to answer the question of «How did digital diplomacy come about?». Digital diplomacy is the result of the evolution of diplomacy itself, that is, we know that diplomacy is divided into three periods: the first goes from ancient diplomacy to the fifteenth century, the second, corresponds from the fifteenth century to the time modern based on international law; and, the third period, arises from the world wars to the present [10].

Recently, with globalization, public diplomacy has evolved, and it is now what we know as digital diplomacy. It is from the 1990s, where a new form of diplomacy begins, restructuring new interests and global, governmental and social needs in the digital ecosystem. According to Olubukola S. Adesina [8, p. 7], «diplomacy has always had to adapt and change to the particular 
communication forms of its environment». That author argues that in an increasingly connected world, «the ability to gather and share information to wide audiences at unprecedented rates has created new opportunities for policy leaders and government departments to share messages and set political agendas beyond traditional channels». The era when diplomats spoke only to other diplomats and scheduled their conversations at ease is over. We are facing a new time, new diplomatic practices are working to succeed in the era of real time. This shows that the transformation of diplomacy and its activity influences the media environment.

The fifth part of the paper presents a vibrant picture of digital diplomacy around the world. It became a key piece of information and diplomatic action. It is developed from public diplomacy and is implemented in the different ministries of foreign affairs through the websites and profiles in the different social networks of both the ministry and the network of representations and consulates.

Likewise, social networks extend beyond interpersonal relationships, in the field of diplomacy it has also come to play a fundamental role. Within each ministry of foreign affairs, it is the responsibility of the communication department: to design, manage and update the web portal, its contents and the proposal and execution of the strategy on social networks. To do this, two conditioning factors and a prior approach are considered. The author claims that digital communication is already an inherent part of diplomatic work and in this framework, social networks constitute the most immediate and relevant instrument. Currently, we can find profiles of different international organizations, ministries, embassies and their representatives on platforms such as: Twitter, Instagram, Facebook Fan Page, Podcast, YouTube, and even TikTok.

Today the different actors of the international community and world leaders use social networks as digital tools to express their position on their foreign policy. The author expresses and explores the ways in which diplomats and government leaders use social networks to promote national interests and improve strategic communications for international cooperation. All these actors consider it useful to develop digital diplomacy to communicate with the citizens of the delegated country and with their fellow citizens or to disseminate their most relevant actions or events, with the coordination of messages among all the actors involved being key. Creating effective digital strategies allows you to communicate in an agile and close way the events of the life of the ministry, consulates and embassies abroad.

The subsequent parts of this article (part 6 and part 7) offer a comprehensive analysis of the benefits and the risks associated with digital diplomacy. While thoroughly describing and explaining the existing and potential benefits the author suggests that digital diplomacy ensures more transparency through direct communication with citizens. Also she demonstrates that due to the lower costs there is a greater call and proximity to the communities. Digital diplomacy also means better consular service for citizens and better positioning of the international image. When describing the risks associated with digital diplomacy, the author mostly mentions information leakage, hacking, and anonymity of Internet users as primary risks.

The conclusions that the author draws in the end of the article affirm that «digital diplomacy has brought about a transformation of the conduct of traditional diplomacy. It defines changes both in structures and processes of ministries of foreign affairs (MFAs)». She follows by asserting that, although digital diplomacy brings with it both opportunities and challenges, «the opportunities appear to overshadow the challenges» [8, p.11].

It is important to emphasize that the article «Foreign policy in an era of digital diplomacy» is a comprehensive descriptive analysis of digital diplomacy as a global phenomenon, as an innovative tool, and already an inherent part of diplomatic work. But it is also one of the first 
attempts to theoretically substantiate and develop the concept of adopting digital diplomacy as the most immediate and relevant instrument of foreign policy-making by the developing countries, especially African countries. The author's argument is that the developing countries are generally «slow in embracing digital diplomacy», but they «cannot afford to be left behind in this tide of digital diplomacy as they can greatly benefit from these emerging diplomatic trends»».

It should be particularly noted that the author makes references to several of sources published by the Russian scholars, thus, acknowledging the growing interest and contribution of Russian researchers to the topic of digitalization of politics and of public policy $[1 ; 9 ; 11]$.

This article has been published in 2016 and it would be interesting to see the evolution of the author's ideas in the pandemic world. The force of a pandemic has triggered digital diplomacy. Many books have been published and conferences have been held to discuss this novel form of diplomacy that has evolved since the dawn of the Internet. It was a logical change, but one that, like many others, did not quite take place. After all, a handshake was the best way to stage a deal, but that has changed and the transition to digital diplomacy has accelerated. It took the force of a global pandemic for digital diplomacy to have been fully used by diplomats around the world.

\section{Литература}

1. Володенков С.В., Федорченко С.Н. Цифровизация современного пространства общественно-политических коммуникаций: научные концепции, модели и сценарии //Вестник Томского государственного университета. Философия. Социология. Политология. - 2021. - № 60. - C. 175-193. DOI: 10.17223/1998863X/60/16.

2. Bjola $C$. Introduction: Making sense of digital diplomacy //C. Bjola \& M. Holmes (Eds.), Digital diplomacy: Theory and practice. - New York, NY: Routledge. 2015. pp. 1-9.

3. Bjola, C., Jiang, L. Social media and public diplomacy: A comparative analysis of the digital diplomatic strategies of the EU, US and Japan in China //C. Bjola \& M. Holmes (Eds.), Digital diplomacy: Theory and practice. NY: Routledge. 2015. P. 71-88.

4. Hanson F. Baked in and wired: eDiplomacy@State //Foreign Policy Paper Series. №30. Washington, DC: Brookings Institution (pp. 1-41). [Электронный pecypc]. URL: https://www.brookings.edu/research/baked-in-and-wired-ediplomacy-state/ (дата обращения: 06.21.2021).

5. Hocking B., Melissen, J. Diplomacy in the digital age. - Clingendael: Netherlands Institute of International Relations. 2015. $52 \mathrm{p}$.

6. Nye J. Soft power: The means to success in world politics. - New York: Public Affairs. 2004. $191 \mathrm{p}$.

7. Nye J. The future of power. - New York: Public Affairs. 2011. 320 p.

8. Olubukola S. Adesina. Foreign policy in an era of digital diplomacy //Cogent Social Sciences. 2017. Vol. 3. Iss. 1. DOI: 10.1080/23311886.2017.1297175. URL: https://www.tandfonline.com/doi/full/10.1080/23311886.2017.1297175 (дата обращения: 06.21.2021).

9. Permyakova L. Digital diplomacy: Areas of work, risks and tools. 2012. [Электронный pecypc]. URL: https://russiancouncil.ru/en/analytics-and-comments/analytics/digital-diplomacyareas-of-work-risks-and-tools/ (дата обращения: 06.21.2021).

10. Seib P. Real-time Diplomacy. Politics and Power in The Social Media Era. - New York: Palgrave MacMillan. 2012. 199 p. 
11. Yakovenko A. Russian digital diplomacy: Clicking through. 2012. [Электронный ресурс]. URL:

http://rbth.com/articles/2012/09/06/russian_digital_diplomacy_clicking_through_18005.html (дата обращения: 06.21.2021).

\section{References}

1. Volodenkov S.V., Fedorchenko S.N. Cifrovizacija sovremennogo prostranstva obshhestvennopoliticheskih kommunikacij: nauchnye koncepcii, modeli i scenarii [Digitalization of the modern space of public and political communications: scientific concepts, models and scenarios]. Vestnik Tomskogo gosudarstvennogo universiteta. Filosofija. Sociologija. Politologija [Vestnik of Tomsk State University. Philosophy. Sociology. Political Science], 2021, I. 60, pp. 175-193, DOI: 10.17223/1998863X/60/16. (In Russian).

2. Bjola C. Introduction: Making sense of digital diplomacy. In C. Bjola \& M. Holmes (Eds.), Digital diplomacy: Theory and practice, NY, Routledge Publ., 2015, pp. 1-9.

3. Bjola C., Jiang L. Social media and public diplomacy: A comparative analysis of the digital diplomatic strategies of the EU, US and Japan in China. In C. Bjola \& M. Holmes (Eds.), Digital diplomacy: Theory and practice, NY, Routledge Publ., 2015, pp. 71-88.

4. Hanson F. Baked in and wired: eDiplomacy@State, Foreign Policy Paper Series. I. 30. Washington, DC: Brookings Institution (pp. 1-41). 2012. Available at https://www.brookings.edu/research/baked-in-and-wired-ediplomacy-state/ (Accessed: 06.21.2021).

5. Hocking B., Melissen J. Diplomacy in the digital age, Clingendael, Netherlands Institute of International Relations Publ., 2015, 52 p.

6. Nye J. Soft power: The means to success in world politics, New York, Public Affairs Publ., 2004, $191 \mathrm{p}$.

7. Nye J. The future of power, New York, Public Affairs Publ., 2011, 320 p.

8. Olubukola S. Adesina. Foreign policy in an era of digital diplomacy, Cogent Social Sciences. 2017. V. 3, I. 1. DOI: 10.1080/23311886.2017.1297175. Available at: https://www.tandfonline.com/doi/full/10.1080/23311886.2017.1297175 (Accessed: 06.21.2021).

9. Permyakova L. Digital diplomacy: Areas of work, risks and tools, 2012. Available at https://russiancouncil.ru/en/analytics-and-comments/analytics/digital-diplomacy-areas-of-workrisks-and-tools/ (Accessed: 06.21.2021).

10. Seib P. Real-time Diplomacy. Politics and Power in The Social Media Era, New York, Palgrave MacMillan Publ., 2012, 199 p.

11. Yakovenko A. Russian digital diplomacy: Clicking through. 2012. Available at http://rbth.com/articles/2012/09/06/russian_digital_diplomacy_clicking_through_18005.html (Accessed: 06.21.2021). 